\title{
School Principal's Strategies in Strengthening Institutional Characters as Educational Leaders for Global Era: A Theoretical Context
}

\author{
Juharyanto \\ Education Administration Department, Faculty of Education, Universitas Negeri Malang, Malang, Indonesia
}

\begin{abstract}
How to cite this paper: Juharyanto(2020). School Principal's Strategies in Strengthening Institutional Characters as Educational Leaders for Global Era: A Theoretical Context. The Educational Review, USA, 4(3), 54-65.

DOI: $10.26855 /$ er.2020.03.002

Received: October 14, 2019

Accepted: November 27, 2019

Published: March 10, 2020

Corresponding author: Juharyanto, Education Administration, Faculty of Education, Universitas Negeri Malang, Malang, Indonesia

Email: Juharyanto.fip@um.ac.id
\end{abstract}

\begin{abstract}
The development of education and schooling from time to time not only been on the aspect of their institutions, but also on the role and core of the content carried out and taught, in accordance with the direction of government policy and global trends. The empowering the character had been becoming an issue the government to be realized. Each learner must be integrating the character values for their nowadays and future era. As a change agent, the principal strategic positions must guarantee to make it happen. The school principal is the key figure and strategically having strong position to strengthen the character. Therefore, it is important to principals to know various strategies to strengthen the students' character, especially in accordance with the global trends and development.
\end{abstract}

Keywords

School Principal's Strategy, Institutional Characters, Global Era

\section{Introduction}

Leadership is an activity in organizing physical resources to achieve organizational goals effectively and efficiently (Schmidt, 2014). Specifically, the principal's leadership is a behavior that portrays human relations in carrying out the tasks of the school organization, even leadership is seen to have a close relationship with personality. Leaders as part of an organization with a strong vision. Leadership will run effectively and efficiently if there is consistency between the values of leadership that are believed in and the behavior that it implements (Owens, Johnson, \& Mitchell, 2013).

Comprehensive studies conducted at Ohio State University suggest a leader-free dimension of behavior namely initiating structure and consideration (Murphy, 2015; Robbins, 1989). Initiating structure describes the relationship between leaders and subordinates. Whereas consideration is the behavior of brotherhood, belief, warmth, attraction and respect. Those two dimensions create LBDQ (Leader Behavior Description Questionnaires) which shows that the two dimensions are separate but not contradictory factors that lie in a four-quadrant continuum line.

Another study conducted by The University of Michigan also puts leader behavior linked to performance effectiveness references (DeCenzo \& Robbins, 2008; Stephen P. Robbins, 2005), which found two forms of leadership behavior, they are production-oriented leadership and employee-centered leadership, which Likert classified into three types of leadership behavior, they are: 1) task-oriented behavior, 2) relation oriented behavior and 3) participative leadership. 
Based on this research, generalizing effective leadership behaviors, among others, effective leaders tend to: 1) establish relationships with subordinates who support and uphold respect, 2) use group methods in supervision and decisions, 3) develop high criteria.

Various leadership studies in different contexts and cultures over the past several decades have concluded that the values of honesty, integrity, alignment with truth, and deep emotional and personal involvement in all organizational personnel are seen as key determinants of the success of an organization's leadership practices (Brown, J. and Townsend, 1997; Hughes, Ginnett, \& Curphy, 2012; Mattox \& Luo, 2003; Mcewen \& Salters, 1997; Swann, 1997). The search for authentic presentation of the values of integrity and truth that respects the variety of context and culture by all organizational resources is a fact and must be fought for and revealed (Bhindi and Duignan, 1997; Duignan, 1988; Imron Arifin; Juharyanto; Mustiningsih; Ahmad Taufiq, 2018). Authentication of these values triggers organizational spiritual motivation and significantly influences the rise of organizational HR empowerment which strengthens the achievement of organizational goals together and perfectly (Covey, 2009).

From some research on educational leadership in schools, it was found that the "passion" of achievement was only obtained through strong leadership awareness that pushed strongly into the individuals of all educational stakeholders encouraged by the exemplary "passion" of achieving principals in the form of meaningful interactions through the use of values leadership values based on adjustments to variations in cultural contexts consistently (Juharyanto, 2012, 2017a). Leaders are not just aware that they are with them, but further and in that they are dynamic human resources who have beautiful ideals in the future and need a place and opportunity to develop optimally for the purpose of the organization as their learning community (Duignan, 1988; Michael Fullan \& Michael Fullan, 2007; Juharyanto, Yusuf Sobri, \& Nurabadi, 2019; Mitchell \& Sackney, 2016; T. J. Sergiovanni \& Green, 2015). Therefore, effective leadership will only occur if ethics and leadership values become the main basis for leaders in carrying out their leadership (Brown, J. and Townsend, 1997).

The concept of leadership must ultimately be interpreted in a broader context, more meaningful, and more relevant to the real life of society and its tendencies (Juharyanto, Sultoni, Arifin, I., Nurabadi, 2019; Juharyanto, 2017b, 2017c). Finally, it must be realized that leadership not only focuses on the ability to influence others, but the power to stimulate the awareness of others through the exploration of self-awareness of the shared strengths of achieving organizational goals. Leadership is basically a process of education and indoctrination of the values of humanist characters personally in the context of the organization in the midst of the current global development that surrounds it. Leadership is in charge of exploring and developing the strength of the overall character of an organization's system through an intersubjective approach based on global trends.

\section{Method}

This study uses the type of library research. This study used in an effort to find and collect, compile, use and interpret existing data. This study is library research, which makes library materials as the main data source intended to explore theories and concepts that have been determined by previous experts, follow the development of research in the field to be examined and avoid duplication of research.

The data used in the study is all library materials that support or are relevant to primary data. Data collection is carried out online and offline books, journals, and proceedings through automatic tracing using the Mendeley desktop application and library visits. All data are studied, analyzed, collected according to their categories, analyzed, and found meaningful findings. 


\section{Results and Discussion}

\subsection{Global Education Trends}

Globalization is a form of realization of the ultimate goal of integrating various aspects of multi-region that must be addressed wisely and appropriately by education. There are at least four things that will be the focus of globalization (Al'Abri, 2011; Wang \& Kühlmann, 2015), including first, multi-region countries becoming a multi-region unit of production. Wise understanding of variations in global characteristics becomes an important part in the process of reflection determining the decisions of an educational organization.

Second, globalization has an impact on high competition, which requires a policy that includes competition policy, consumer protection, Intellectual Property Rights (IPR), taxation, and E-Commerce as well as integrative \& comprehensive views of leadership. Third, globalization is an area that has economic development as a basic reference in measuring human welfare. Competitiveness and dynamism in economic business will be enhanced by facilitating the development of human resources in terms of capacity building, finance, and technology. Fourth, globalization will be fully integrated in all sectors, including the education sector.

Based on the four focuses of globalization, the gap between regional countries will be smaller, if of course supported by balanced HR capabilities. Although in some cases Indonesia also benefits from the production of goods that are not owned by other countries in the region, but if the quality of Indonesian human resources does not experience significant progress, then it is not impossible, Indonesia, with the largest population attached to consumptive, shock, instant, and so only become the main target of regional countries that have high quality (production) HR. The main key in dealing with it is increasing the competence of Indonesian human resources so that they can take advantage of comparative advantage into competitive advantage, with efforts to increase national human resource competitiveness (Siradjuddin, Azmi, 2014) and globally.

The practice of education in the globalization era is more dominated by increasingly strong global product tools. Education does not only process in its traditional form but will further (ongoing) take place indefinitely in space and time. Education in the global era will experience a metamorphosis into "classroom-less" and paper-less e-paper, where the trust center of students and the public will shift to data and information products based on software technology, compared to the educators (Juharyanto, Sultoni, Arifin, I., Nurabadi, 2019; Juharyanto, 2014).

The response to the globalization presence must be supported by high human resource capacity, strong mastery of science, foreign languages and technology, and a strong leadership commitment and ability to make itself a model (uswah) as a reliable agent of change. Efforts to improve the quality of human resources can be done by efforts of synergy between the government, business actors, and academics to set professional competency standards in each sector. The acceleration of improving the quality of human resources to compete in the global 2015 must be implemented immediately in order to achieve progress and catch up with other countries.

The response to these global trends is certainly not just a personal effort for everyone in an organization. Strengthening local characteristics based on personal potential should be an organizational agreement. However, the existence of an educational institution, whether it is realized or not, is the main backbone that is expected by the community to be able to prepare their students' generation to become strong citizens in the global era while still holding fast to local characteristics. Educational institutions must be tough before making efforts to suspend their citizens. Of course, the leading figure in carrying out these efforts lies with the principal. 


\subsection{Building the Character of Educational Institutions}

Character education includes dimensions of moral reasoning, moral feeling, and moral behavior (Lickona, 1996, 2004), or in the full sense as morality which includes moral judgment and moral behavior both prohibition-oriented morality and pro-social morality (Ausubel \& Piaget, 1968; Piaget, J., \& Inhelder, 2010). Character education should be developed by applying a holistic approach, with the understanding that "Effective character education is not adding a program or set of programs. Rather it is a transformation of the culture and life of the school" (Berkowitz, 2003; Berkowitz \& Hoppe, 2009). Lickona (1996) asserts that: "In character education, it's clear we want our children to be able to judge what is right, care deeply about what is right, and then do what they believe to be right-event in the face of pressure form without and temptation from within.

The basic value system of an efficient organization is the values that are built and strengthened through a form of leadership based on strong values and truly practiced by leaders with exemplary forms, so that the entire organizational system is bound to a homogeneity of characters that strengthens the organization itself. The value system is "the conceptions of life in the mind as citizens of the things they must consider very valuable in life" (Marzali, 2014; Prof. Dr. Koentjaraningrat, 2007), while behavior is a "function of interaction between people and the environment" (Owens et al., 2013). The product of that interaction can be in the form of good behavior that brings a sense of security, satisfaction and others and bad behavior that can cause fear, hatred and others. In organizations, according to the theory it can be in the form of "office holders" (Owens et al., 2013), "employees and customers" (Mattox \& Luo, 2003), and both interact with their environment.

In this case the leader of the organization can start by creating a vision that can be trusted by members, communicating the vision to all members of the organization and then institutionalizing the vision through various behaviors, rituals, ceremonies, and symbols, as well as through organizational systems and policies (Nurhasanah, Nadiroh, \& Nafiah, 2019; Timmermans, van der Werf, \& Rubie-Davies, 2019). Leaders based on character values will gain the trust and respect of all members of the organization when the leader is able to concretely demonstrate the existence of enthusiasm, perseverance, struggle and sacrifice in carrying out the values of organizational character. Strengthening the character of educational institutions means strengthening the values of character (good and right) into the personal leader itself. The success of self-strengthening will have an impact on the response of character modeling by all resources in the school system itself.

Every human being must have a positive character in the form of a positive attitude in the view of the general public. These positive attitudes include optimism, faith, quick recovery, sportsmanship, enthusiasm, sensitivity, humor, gratitude, humility and hope. These virtues undergo a process of internalization and dissemination into individuals and social relations within an organization.

Allport does not distinguish between character and personality (F. H. Allport \& Allport, 1921; G. W. Allport, 1927; Carducci, 2009). Both are dynamic organizations in the individual as a psychophysical system that determines the unique way of adjusting to the environment. Character is used more in a normative sense. In the original language, Allport called "character is personality evaluated", on the contrary "personality is character devaluated". According to Allport, humans are organisms that at birth in childhood are biological creatures, then change / develop in adulthood into individuals whose ego is always developing.

Denison states that culture can affect organizational performance, the organizational culture model is based on cultural traits namely involvement, consistency, adaptability and mission (Ahmady, Nikooravesh, \& Mehrpour, 2016; Denison, 1996). Wijanarko states the values and norms control the behavior of members of the organization, so that organizational culture will form certain behavioral patterns of its members (Damayanti, Widjanarko, \& Purnami, 2016). 
Thus, the character played by the principal as an educational leader becomes very important and very strong in determining and developing organizational culture.

\subsection{Principal as Model Strengthening Institutional Characters}

The principal is a professional official in a school organization whose job is to manage all organizational resources and work closely with teachers in educating students to achieve educational goals and understanding all school needs. Professionalism of school principals can be achieved if they meet certain requirements and criteria that have been applied in Minister of National Education Regulation (Permendiknas) No. 13 of 2007. Hanson states that for school principals to be able to carry out their functions based on their duties and responsibilities, a school principal must have competence, which then becomes one of the basic references for the issuance of policies on teacher certification (Bafadal, 2008).

There are five competencies that must be possessed by school principals in accordance with Permendiknas No. 13 of 2007, namely: personal competence, managerial, entrepreneurship, supervision and social, although in its implementation often hampered due to several things. For example, the low mentality of school principals, lack of motivation and enthusiasm and lack of discipline in performing tasks, and often arriving late, insights of principals that are still narrow, even ambiguities in the implementation of political domains on the basis of vested interests often obscure the role of professional principals to improve quality teacher quality and education quality nationally (Amanchukwu et al., 2015), because the existence of schools cannot be separated from political terminology (Cherian, F. \& Daniel, Y., 2008). Within this framework, the socialization of organizational culture (Brinia, Zimianiti, \& Panagiotopoulos, 2014; Narti, Setyosari, Degeng, \& Dwiyogo, 2016) needs to be carried out in the context of the consistency of the spirit of decentralization (Bush, 2016; Su, Gamage, \& Mininberg, 2003) in order to make the process of changing schools become more qualified and able to strengthen values the character of the entire school academic community, especially students.

The principal is not only as an instructional leader but also as an agent of change and a real facilitator working in school reform (Cummings et al., 2011). Bafadal found that the success of the process of implementing change in primary schools was supported by internal agents, especially school principals (Bafadal, 1995).

Some studies related to the theme of elementary school change has been carried out along with its findings that should be used as a reference for developers and education practitioners, including Lezotte et al who examined the effect of effective school characteristics on learning achievement (Creemers \& Reezigt, 2005; Lezotte, 1989); Purnell \& Gotts who examined the involvement of parents in guiding children at home (Gotts \& Purnell, 1987a, 1987b) ; Goodlad who examines successful schools (L. Goodlad, 2017; R. Goodlad, Burton, \& Croft, 2005); Frymeir, et al who examined one hundred good schools through change (Devries et al., 2013); Gibbons with research that emphasizes effective school research through the implementation of the School Improvement Program (Hokanson \& Gibbons, 2014); Purkey \& Smith who examined effective schools by emphasizing specific teaching programs (Purkey \& Smith, 1983); Rutter who examined the key role of principals in improving the quality of student output (T. J. et al. Sergiovanni, 1987); Davis who examined effective schools and effective teachers; and others (Palmer, Wehmeyer, Shogren, Williams-Diehm, \& Soukup, 2012; Tobin, 2014). The various studies indicate the importance of school organizations as an integral part in accommodating the creation of good schools (read: effective, quality), which are organizationally very determined by the principal.

From the various opinions above it is known that the principal is a key person who is crucial in changing the direction in which the school is intended. The principal is the first and foremost person responsible for the success of 
strengthening the character of the educational institution's resources. Failure and success of the strengthening is entirely the responsibility of the principal, as the foremost leader and agent of change in the school. In short, school principal modeling which is visualized into character attitudes and behaviors in the daily presence, becomes the main key to the success and failure of educational institutions that he guides.

\subsection{Educational Institutional Character Strengthening Strategies}

The principal is a professional official in a school organization whose job is to manage all organizational resources and work together with teachers to strengthen character values to students through education and teaching in schools. The principal is a teacher who is added to his position as the principal because of his expertise in aspects of knowledge, attitudes, and skills. All of these aspects are integrated into him as a whole and proportionally so that he becomes a different person when compared to the existence of teachers and other administrative officers. Thus, strengthening the character of all resources, is not a difficult task for school principals with the provision of these perfect aspects of competence.

In fact, not all school principals are able to make efforts to strengthen the character. Principals are often trapped in the dominance of administrative and technical activities, where they are basically also obliged to carry out other functions as leaders, managers, and supervisors in their schools. A good understanding of these functions needs to be internalized and improved as a guarantee of the strengthened character of students as mandated by the acts. In addition, several strategies that can be carried out by school principals in strengthening character values to students include: 1) Integration of overall educational institutions; 2) Integration of total competencies into the daily aspects of school culture; 3) Strengthening discipline commitment; 4) cooperation with third parties; 5) Ongoing monitoring and evaluation; 6) Routine Progress Reporting; 7) Open reflection (Juharyanto, 2017c).

The main priority in strengthening character is through the cultivation of educational values that always strive to mature humanity as a whole. Suwarno states that in order to carry out these educational efforts, schools cannot do it alone without the involvement of other parties, family and community (Mukhlisoh \& Suwarno, 2019; Suwarno \& Farida, 2015). This awareness has consequences for schools to always conduct intensive coordination in strengthening the character of students as part of the family and community, receiving input, and planning the same actions in developing students. Involving the community and family has an impact on increasing community awareness of school programs, as well as being a foundation for all three parties to find solutions to all problems related to the weakening of the character they want and strengthen them together.

One aspect that is emphasized in the process of internalization of character-based values in the process of student character development is the value of professionalism and awareness of his competency as the principal. Motivating students to always apply character values should be done through exemplary modeling, where principals zero in on the realization of their competence in real-life life. Moving students means presenting a stimulus of good values through the embodiment of these values in front of everyone, especially students. Integration of these character values can also be done through visualization of character values that are integrated with educational displays that are spread openly into every aspect/infrastructure of the education unit.

Strengthening character values is closely related to strengthening disciplinary commitment. Disciplinary commitment should be built on the basis of the potential of individual students. The implication is that the performance of disciplinary indicators between individuals is different, as are the different disciplinary actions they will receive. The rules in the disciplinary framework to build the character that is arranged by the school, so that it is uniform, is an indication that students' individuality is not encompassed. 
The awareness of the importance of the involvement of implementing institutions and reinforcing character values in strengthening the character values of students must be fostered and strengthened to all school resources. The collaboration with various institutions also seems to need more serious attention from the school principal. Specifically, the assertion of the division of roles and the definition of coordination between the two, starting from the form of coordination, the monitoring and evaluation system, as well as the clarity of character building and integrative values of internalizing the desired character values. Comparative study activities, overnight paramedics, internships, bringing in resource persons, outbound activities, etc. are some examples of third-party collaboration. Empowerment of school committees as organizations that have a valid ability to reflect the character of the community, is very important to do. The character developed certainly remains based on community loyalty, where the school committee has the knowledge and experience about it.

The activity of monitoring and evaluating character strengthening refers to the principle of on-going monitoring and evaluation. The activity is carried out with the intention to be able to reflect on all forms or performances of character strengthening carried out by students and all school resources. These activities are not limited to time and place, they take place all the time and in all conditions. Each resource has a relatively equal role in carrying out these activities.

The progress report on the achievement of character strengthening should be a routine and perfectly planned activity. Routine activities often do not ignore the substance of the activity itself. As a result, activity after activity is only carried out in order to abort scheduled obligations. Therefore, the activity must be planned in such a way that the substance of its progress report generates a constructive conclusion for the improvement of the joint character strengthening program among the three existing education centers.

Every effort to strengthen the character should be reflected openly by all the parties involved. Reflection is done through the approach of religion, either one-way reflection, two-way reflection, reflection and multi-ways, depending on the scope, resources, and performance targets learners' characters.

In addition, according to Bezzina, there are several strategies developed in the context of decentralization and institutional transparency, including: 1) Developing a vision; 2) Main Ideology; 3) Facing Challenges; 4) Learners; 5) imagination; 6) promote values; 7) empowerment; 8) collegial leadership; and 9) heroic (G. Bezzina, 1995; M. Bezzina, 2012).

Research conducted by Buell, Champy, Fullan, Terry concluded that the effectiveness of a change is determined by the development of a well-distributed vision for the entire organization (Buell, 1992; Champy, 1995; M Fullan, 2013; Robert W Terry; Harlan Cleveland, 1993). This condition requires the wisdom and intention of top-level institutions to be able to work together to help the institutions below them shape their future through the formulation and development of their own vision, of course, a vision that is broken down from the vision and mission of the institutions above it.

The main ideology is defined as the character of an organization, whose existence becomes the glue for each institution to develop and advance together to achieve a vision in a regulative normative harmony. The main ideology includes basic values, core goals, and visualizing the future. Basic values are very important and their existence is eternal for an organization that is in the learning process. These basic values are rooted in local values that are massively recognized. The values of honesty, trustworthiness, integrity, ape work, endless self-improvement efforts, empowerment and creativity, service, and mindset, attitudes, holistic actions, do not have to change because of changes that occur outside, but instead become the best reference for the occurrence changes in the organizational system (Collins \& Porras, 1996). The core objectives emphasize the reasons why organizations are created, created or formed. Effective core goals can help members reflect on their ideal motivation in achieving organizational goals. To visualize the future is to set clear goals and strategies for achieving future goals. Fritz states that organizational development is largely determined by the 
clarity and firmness of the purpose of the organization's mission statement (Fritz, 1996). For organizations that are always learning, the mission will not be meaningful if the value of mission does not penetrate the educator's inner self, is patterned in his attitudes and actions, then refracts to all corners of his organization (inner edge) which are extrapolated into the formulation of more concrete and realistic goals. Thus, the strategy also includes the formulation of performance indicators or success criteria as a basis for clarification in terms of the dimensions of time, energy, cost, and the activity itself (Ainscow Beresford, J., Harris, A., Hopkins, D., Southworth, G., and West, M., 2000).

The failure of educational practices in the context of the decentralization of education by promoting the independence and autonomy of management and leadership has not entirely successful. The cause is the action taken in preparing resources leaning to the conceptual technical level of the desired aspects of change, and paying less attention to the aspects of human characters (C. Bezzina, 2000). Effective management for an organization, apparently cannot be taught, because management is not just a collection of mechanical tasks, but the interaction of humanistic characters (Harrison, D., Price, K., \& Bell, 1998), and the emphasis on aspects of the public relations character affects the effective future leadership (Adair, 2003, 2007; Peter Mortimore; Jo Mortimore, 1991), and integrated with humanistic character, which, according to Duignan is the leader of the "full-blooded creatures who are politically and spiritually aware, Earthly and practical (Duignan, 1988).

The principle of lifelong learning must be upheld and practiced by leaders (Crowther, F. and Limerick, 1988). Leaders need to promote an environment where active learning can occur. Learning needs to be seen as a social activity (Sylvia Downs, 1995) where everyone has a role to play in helping people to learn.

Visionary leaders always make a "mental leap" by changing "impossible conditions now" to "must happen in the future". They are always bound by such imagination with high commitment and creativity, exploring new energy and new ways that support organizational life. Important characteristics of future leaders are always trying to be a model / role model and communicating their example through the depth of their beliefs and ideas and daily behavior, or according to Boyatzis referred to as resonant leaders (Boyatzis \& McKee, 2006).

The leader of the global era becomes the creator of a value system as well as the center of echoes of these values which then resonates around the whole corner of the organization according to certain principles that are recognized for reliability or Covey calls it the term a value system centered round principle (Covey, 2009). Leaders will succeed if they try to attach their management and leadership behaviors to the principles of personal integrity, credibility and mutual trust (Brown \& Posner, 2001), and commitment to ethical and moral values such as compassion, humility and service (Juharyanto, 2017a) so that organizational structures, processes and practices will be built, maintained, maintained and developed. Of course, the promotion of these values will run well when framed by the principle of al Muhafadatu la a laa Qodimis Sholeh wal Akhdu bil Jadidil Ashlah (maintaining old good values and are willing to take new relevant values) (Juharyanto, 2012).

Subordinates sometimes admire leaders who delegate their authority, which makes subordinates feel strong and capable. Subordinates give back trust, support and praise to the leader, and this helps to strengthen the leader and the organization's vision.

Leadership cannot be the prerogative of one person. Future leaders need to be trained to master the art of forming teams, collaborating through teams rather than directing and giving orders. Collegial leadership encourages prolonged organizational resilience.

Management basically has a heroic dimension because it is always associated with challenges and the pursuit of success and there is no reason to run away from responsibility (Thomas Teal, 1996). The leader is a person who is confident and always willing to challenge himself to do as many things as possible that are beyond his abilities and at the same time 
always willing to accept the internal and external challenges of his organization.

\section{Conclusions}

From the previous description, it can be concluded that among others: 1) Globalization is necessary and unavoidable, as the impact that closely accompanies it. The school principal as the leader of an educational institution is obliged to make him/herself as a model for strengthening global values and competencies; 2) the high-quality human resources are only produced by the high-quality education managed by qualified leaders; 3) Strengthening character into educational institutions can be done with a variety of strategies, including: (1) Integration of overall educational institutions; (2) Integration of total competencies into the daily aspects of school culture; (3) Strengthening disciplinary commitment; (4) cooperation with third parties; (5) On going monitoring and evaluation; (6) Routine Progress Reporting; (7) Open reflection; (8) building a culture of independence; (9) developing a vision; (10) reinforce the main ideology; (11) building readiness for the challenge: learning, imagination, the promotion of values, empowerment, collegial leadership and heroic spirit.

\section{Acknowledgements}

The research was partly funded by Universitas Negeri Malang.

\section{References}

Adair, J. (2003). Effective Leadership: How to Develop Leadership Skills.

Adair, J. (2007). Develop Your Leadership Skills. Philadelphia, USA: Kogan Page.

Ahmady, G. A., Nikooravesh, A., \& Mehrpour, M. (2016). Effect of Organizational Culture on knowledge Management Based on Denison Model. Procedia - Social and Behavioral Sciences. https://doi.org/10.1016/j.sbspro.2016.09.049

Ainscow Beresford, J., Harris, A., Hopkins, D., Southworth, G., and West, M., M. (2000). Creating the Conditions for School Improvement (Vol. 2nd). David Fulton.

Al'Abri, K. (2011). The Impact of Globalization on Education Policy of Developing Countries: Oman as an Example. Literacy Information and Computer Education Journal, 2(4), 491-502. https://doi.org/10.20533/licej.2040.2589.2011.0068

Allport, F. H., \& Allport, G. W. (1921). Personality Traits: Their Classification and Measurement. Journal of Abnormal Psychology and Social Psychology. https://doi.org/10.1037/h0069790

Allport, G. W. (1927). Concepts of trait and personality. Psychological Bulletin. https://doi.org/10.1037/h0073629

Amanchukwu, R. N., Stanley, G. J., Ololube, N. P., Amanchukwu, R. N., Stanley, G. J., \& Ololube, N. P. (2015). A Review of Leadership Theories, Principles and Styles and Their Relevance to Educational Management. Management.

Ausubel, D. P., \& Piaget, J. (1968). Ausubel's Learning Theory. Fakultas Pendidikan.

Bafadal, I. (1995). Proses Perubahan di Sekolah: Studi Multisitus pada Tiga Sekolah Dasar yang Baik di Sumekar. Institut Kaguruan dan Ilmu Pendidikan, Malang.

Berkowitz, M. W. (2003). The Science of Character Education. Bringing in a New Era in Character Education.

Berkowitz, M. W., \& Hoppe, M. A. (2009). Character education and gifted children. High Ability Studies. https://doi.org/10.1080/13598130903358493

Bezzina, C. (2000). Educational leadership for twenty-first century Malta: breaking the bonds of dependency. International Journal of Educational Management, 299-307. https://doi.org/10.1108/09513540010378950

Bezzina, G. (1995). The Maltese Primary School Principalship: Perception, Roles and Responsibilities. Brunei University School of Education.

Bezzina, M. (2012). Paying Attention to Moral Purpose in Leading Learning: Lessons from the Leaders Transforming Learning and Learners Project. Educational Management Administration \& Leadership, 40(2), $248-271$. https://doi.org/10.1177/1741143211427979

Bhindi and Duignan. (1997). Leadership for a New Century, Authenticity, Intentionality, Spirituality and Sensibility. Educational Management \& Administration, 25(2), 117. 
Boyatzis, R., \& McKee, A. (2006). Resonant Leadership. Personnel Psychology, 59(2), 467-471. https://doi.org/10.1111/j.1744-6570.2006.00043_4.x

Brinia, V., Zimianiti, L., \& Panagiotopoulos, K. (2014). The role of the principal's emotional intelligence in primary education leadership. Educational Management Administration \& Leadership, 42(4 Suppl), 28-44. https://doi.org/10.1177/1741143213513183

Brown, J. and Townsend, R. (1997). Developing an ethical framework, Thrust for Educational Leadership, 27(3), $12-14$.

Brown, L. M., \& Posner, B. Z. (2001). Exploring the relationship between learning and leadership. Leadership \& Organization Development Journal, 22(6), 274-280. https://doi.org/10.1108/01437730110403204

Buell, N. A. (1992). Principal ', s Leadership Challenge E ffective school leaders have. October, 88-92. https://doi.org/10.1177/019263659207654214

Bush, T. (2016). Preparing new principals: Professional and organisational socialisation, 44(1), 3-5. https://doi.org/10.1177/1741143215620317

Carducci, B. J. (2009). The Psychology of Personality: Viewpoints, Research, and Applications. Wiley Blackwell.

Champy, J. (1995). Reengineering management: The mandate for new leadership. Industry Week (Vol. 244). New York: Harper-Collins. https://doi.org/10.1017/CBO9781107415324.004

Cherian, F. \& Daniel, Y. (2008). Principal Leadership in New Teacher Induction: Becoming Agents of Change. International Journal of Education Policy \& Leadership, 3(2), 1-11.

Collins, J., \& Porras, J. (1996). Building Your Company' S Vision. Harvard Business Review, 74(5), 65-77.

Covey, S. (2009). Leadership great leaders, great teams, great results.

Creemers, B. P. M., \& Reezigt, G. J. (2005). The role of school and classroom climate in elementary school learning environments. In School Climate: Measuring, Improving and Sustaining Healthy Learning Environments. https://doi.org/10.4324/9780203983980-8

Crowther, F. and Limerick, B. (1988). Leaders as learners: implications for postmodern leader development. International Studies in Educational Administration, 26(2).

Cummings, W. K., Arimoto, A., Enders, J., Metcalfe, A., Musselin, C., Santiago, R., ... Wohluter, C. (2011). Changing Governance and Management in Higher Education.

Damayanti, D. F., Widjanarko, B., \& Purnami, C. T. (2016). Analisis Peran Manajerial Pengurus Ikatan Bidan Indonesia (IBI) dalam Pelaksanaan Program Peningkatan Pemberian Asi (PPASI) di Wilayah Kota Pontianak. Jurnal Manajemen Kesehatan Indonesia.

DeCenzo, D. A., \& Robbins, S. P. (2008). Fundamentals of Human Resource Management (10th edition) BY David A. DeCenzo, Stephen P. Robbins-Wiley (2009).

Denison, D. R. (1996). What is the Difference between Organizational Culture and Organizational Climate? A Native's Point of View on a Decade of Paradigm Wars. The Academy of Management Review. https://doi.org/10.2307/258997

Devries, K. M., Allen, E., Child, J. C., Walakira, E., Parkes, J., Elbourne, D., ... Naker, D. (2013). The Good Schools Toolkit to prevent violence against children in Ugandan primary schools: Study protocol for a cluster randomised controlled trial. Trials. https://doi.org/10.1186/1745-6215-14-232

Duignan, P. (1988). Authenticity in leadership: the rhetoric and the reality. In ATEE 23rd Annual Conference. Limerick, Ireland.

Fritz, R. (1996). Corporate Tides: The Inescapable Laws of Organizational Structure. San Francisco: Berret-Koehler Publishers. Retrieved from http://www.amazon.com/Corporate-Tides-Inescapable-Organizational-Structure/dp/1881052885

Fullan, M. (2013). Great to Excellent: Launching the next stage of Ontario's education agenda.

Fullan, Michael, \& Michael Fullan. (2007). The New Meaning of Educational Change. New York: Teachers College Press.

Goodlad, L. (2017). Moral character. In Historicism and the Human Sciences in Victorian Britain. https://doi.org/10.1017/9781316711286.006

Goodlad, R., Burton, P., \& Croft, J. (2005). Effectiveness at what? The processes and impact of community involvement in area-based initiatives. Environment and Planning C: Government and Policy. https://doi.org/10.1068/c45m

Gotts, E. E., \& Purnell, R. F. (1987a). Practicing School-Family Relations in Urban Settings. Education and Urban Society. https://doi.org/10.1177/0013124587019002009

Gotts, E. E., \& Purnell, R. F. (1987b). School-family relations and effective schools. Education and Urban Society. https://doi.org/10.1177/0013124587019002001

Harrison, D., Price, K., \& Bell, M. (1998). Beyond relational demography: Time and the effects of surface- and deep-level diversity on work group cohesion. Academy of Management Journal, 41, 96-107.

Hokanson, B., \& Gibbons, A. (2014). Design in Educational Technology. Design Thinking, Design Process, and the Design Studio. https://doi.org/10.1007/978-3-319-00927-8 
Hughes, R. L., Ginnett, R. C., \& Curphy, G. J. (2012). Leadership: Memperkaya pelajaran dari pengalaman. Edisi Tujuh. Jakarta: Penerbit Salemba Humanika. Jakarta: Salemba Humanika.

Imron Arifin; Juharyanto, etc; Mustiningsih; Ahmad Taufiq. (2018). Islamic Crash Course as a Leadership Strategy of School Principals in Strengthening School Organizational Culture. SAGE Open, 8(3), 215824401879984.

https://doi.org/10.1177/2158244018799849

Juharyanto, Sultoni, Arifin, I., Nurabadi, A. (2019). Kepemimpinan Kepala Sekolah dalam Penguatan Peran Multi-Stakeholders Forum: Masalah dan Strategi Solutif Peningkatan Mutu SD - SMP Satu Atap di Daerah Terpencil. Sekolah Dasar: Kajian Teori Dan Praktik Pendidikan, 82(01), 1-10.

Juharyanto. (2012). Implementasi Kompetensi Kepala Sekolah Sebagai Agen Perubahan pada Sekolah Berprestasi: Studi Multi Kasus Pada Tiga SD/MI Berprestasi Di Kabupaten Bondowoso, Kabupaten Jember dan Kabupaten Situbondo. Ph.D Thesis Universitas Negeri Malang.

Juharyanto. (2014). Internalisasi Nilai Karakter Dalam Membangun Kultur Organisasi Pendidikan Studi Kasus pada Sekolah Tinggi Agama Islam Bondowoso. Jurnal Pendidikan Lentera Dinas Pendidikan Kabupaten Bondowoso, 1(1). Retrieved from https://www.scribd.com/doc/212222730/Isi-Jurnal-Edisi-Perdana-14-02-2014

Juharyanto. (2017a). Kepemimpinan unggul Kepala Sekolah Dasar Daerah Terpencil (Studi Multisitus pada Sekolah Dasar di Kabupaten Bondowoso). Jurnal Sekolah Dasar, 1(Tahun 26). Retrieved from url: http://jurnal.fip.um.ac.id/sekolahdasar

Juharyanto. (2017b). Kepemimpinan unggul Kepala Sekolah Dasar Daerah Terpencil (Studi Multisitus pada Sekolah Dasar di Kabupaten Bondowoso). Jurnal Sekolah Dasar, 1(Tahun 26), 89-100. Retrieved from url: http://jurnal.fip.um.ac.id/sekolahdasar

Juharyanto, J. (2017c). Implementation of Principal Personality Competency as a Change Agent on School Achievement in Remote Area One Roof School. Proceedings of the 2nd International Conference on Educational Management and Administration (CoEMA 2017), (October). https://doi.org/10.2991/coema-17.2017.7

Juharyanto, Yusuf Sobri, A., \& Nurabadi, A. (2019). The Principal Leadership in Strengthening Elementary School Education Character. https://doi.org/10.2991/icet-18.2018.38

Lezotte, L. W. (1989). School improvement based on the effective schools research. International Journal of Educational Research. https://doi.org/10.1016/0883-0355(89)90031-1

Lickona, T. (1996). Eleven principles of effective character education. Journal of Moral Education, 25(1), 93-100. https://doi.org/10.1080/0305724960250110

Lickona, T. (2004). Educating for character: how our schools can teach respect and responsibility. New York: The New York Times Company.

Marzali, A. (2014). Pergeseran Orientasi Nilai Kultural dan Keagamaan di Indonesia (Sebuah Esai dalam Rangka Mengenang Almarhum Prof. Koentjaraningrat). Antropologi Indonesia. https://doi.org/10.7454/ai.v30i3.3566

Mattox, M., \& Luo, D. (2003). Partnering: the new face of leadership. Leadership. https://doi.org/10.1108/17511870810893010

Mcewen, A., \& Salters, M. (1997). Values and Management: The role of the primary school headteacher. School Leadership \& Management, 17(1), 69-80. https://doi.org/10.1080/13632439770177

Mitchell, C., \& Sackney, L. (2016). School improvement in high-capacity schools: Educational leadership and living-systems ontology, 44(5), 853-868. https://doi.org/10.1177/1741143214564772

Mukhlisoh, M., \& Suwarno, S. (2019). Implementasi Manajemen Pendidikan Karakter Di Sekolah. Jurnal Darussalam: Jurnal Pendidikan, Komunikasi Dan Pemikiran Hukum Islam. https://doi.org/10.30739/darussalam.v11i1.449

Murphy, J. (2015). Creating communities of professionalism: addressing cultural and structural barriers. Journal of Educational Administration, 53(2), 154-176. https://doi.org/10.1108/JEA-10-2013-0119

Narti, Y., Setyosari, P., Degeng, I. N. S., \& Dwiyogo, W. D. (2016). Thematic Learning Implementation in Elementary School (Phenomenology Studies in Pamotan SDN 01 and 01 Majangtengah Dampit Malang). International Journal of Science and Research, 5(11), 1849-1855. https://doi.org/10.21275/ART20163223

Nurhasanah, N., Nadiroh, \& Nafiah, M. (2019). Developed Students Character at Elementary School through Wordless Picture Book. https://doi.org/10.2991/icesshum-19.2019.3

Owens, B. P., Johnson, M. D., \& Mitchell, T. R. (2013). Expressed humility in organizations: Implications for performance, teams, and leadership. Organization Science. https://doi.org/10.1287/orsc.1120.0795

Palmer, S. B., Wehmeyer, M. L., Shogren, K. A., Williams-Diehm, K. L., \& Soukup, J. H. (2012). An Evaluation of the Beyond High School Model on the Self- Determination of Students With Intellectual Disability. Career Development for Exceptional Individuals. https://doi.org/10.1177/0885728811432165

Peter Mortimore; Jo Mortimore. (1991). The Secondary head : roles, responsibilities, and reflections. London: P. Chapman Pub. 
Piaget, J., \& Inhelder, B. (2010). Psikologi Anak. Yogyakarta: Pustaka Pelajar.

Prof. Dr. Koentjaraningrat. (2007). “Manusia dan Kebudayaan Di Indonesia.” Djambatan.

https://doi.org/10.1016/s0044-8486(97)00050-1

Purkey, S. C., \& Smith, M. S. (1983). Effective Schools: A Review. The Elementary School Journal. https://doi.org/10.1086/461325

Robbins, S. P. (1989). Organizational behavior : concepts, controversies, and applications. Englewood Clift, New Jersey: Prentice Hall. Retrieved from http://www.worldcat.org/title/organizational-behavior-concepts-controversies-and-applications/oclc/20862665

Robert W Terry; Harlan Cleveland. (1993). Authentic leadership : courage in action. San Francisco: Jossey-Bass Publishers.

Schmidt, G. B. (2014). Virtual leadership: An important leadership context. Industrial and Organizational Psychology. https://doi.org/10.1111/iops.12129

Sergiovanni, T. J. et al. (1987). Educational Governance and Administration (2nd ed.). Englewood Cliffs, NJ: Prentice-Hall, Inc.

Sergiovanni, T. J., \& Green, R. L. (2015). Principalship: A reflective practice perspective (6th ed.). Boston: Allyn and Bacon, Inc.

Siradjuddin, Azmi, S. A. (2014). Hukum Ekonomi. Jurnal Adzkiya.

Stephen P. Robbins, M. K. C. (2005). Management. Pearson Prentice Hall.

Su, Z., Gamage, D., \& Mininberg, E. (2003). Professional preparation and development of school leaders in Australia and the USA. International Education Journal, 4(1), 42-59.

Suwarno, \& Farida, L. A. (2015). Aktualisasi Bimbingan dan Konseling pada Pendidikan Dasar Menuju Peserta Didik yang Berkarakter. Prosiding Seminar Nasional Dan Call For Papers.

Swann, R. (1997). Compassionate leadership in schools. International Studies in Educational Administration, 26(1). Retrieved from http://minerva-access.saturn.its.unimelb.edu.au/handle/123456789/208463

Sylvia Downs. (1995). Learning at work : effective strategies for making things happen. London: Kogan Page.

Thomas Teal. (1996). Invite Friends. Harvard Business Review, 1-6.

Timmermans, A. C., van der Werf, M. P. C. G., \& Rubie-Davies, C. M. (2019). The interpersonal character of teacher expectations: The perceived teacher-student relationship as an antecedent of teachers' track recommendations. Journal of School Psychology. https://doi.org/10.1016/j.jsp.2019.02.004

Tobin, J. (2014). Management and leadership issues for school building leaders. NCPEA International Journal of Educational Leadership Preparation.

Wang, J., \& Kühlmann, T. M. (2015). Globalization of leadership development: An empirical study of impact on German and Chinese managers. Globalization of Leadership Development: An Empirical Study of Impact on German and Chinese Managers, 1-426. https://doi.org/10.1007/978-3-658-06864-6 